\title{
Factors Affecting Indonesian Nurse Behavior in Applying Universal Precaution
}

\section{Wansuzusino Wansuzusino ${ }^{1}$}

${ }^{1}$ Messaieed Medical Center Qatar Petroleum

\section{Article Info}

Article History:
Accepted September 30th,
2019

Key words:

Universal precaution;

Behavior; Nurse

\section{INTRODUCTION}

Universal precautions are one of the strategies that have been recommended by the Centers for Disease Control and Prevention (CDC) in efforts to control infections and transmit diseases in health facilities, such as hospitals, clinical clinics,
Abstract

Professional nurses in carrying out their roles and functions on a daily basis, are always at risk of contacting various diseases. Transmission of the disease can occur via direct or indirect contact, transmission can be through droplet transmission, and airborne transmission (CDC). Universal precautions are one of the strategies that have been recommended by the Centers for Disease Control and Prevention (CDC) in efforts to control infection and disease transmission in health facilities, such as hospitals, doctors' practices, and other health care centers. The purpose of the study was to determine the factors that influence the behavior of Indonesian nurses in implementing universal precaution in the Center for Health Services in Qatar. The research process was carried out in October 2011 in Qatar with a total sampling method, a total sample of 52 respondents. The results showed that most Indonesian nurses in Qatar with a Diploma in Nursing, had work experience of more than 6 years. Placed in various locations such as; ambulance services, company clinics and hospitals. There was no significant relationship between knowledge and nurses behavior in applying Universal Precaution $(p<0.05)$. There was no significant relationship between attitude and behavior of Indonesian nurses in implementing Universal Precaution ( $\mathrm{p}<0.05)$. There was no significant relationship between motivation and the behavior of Indonesian nurses in implementing Universal Precaution ( $p<0.05$ ). There was a significant relationship ( $p<0.05)$ between the means and the behavior of Indonesian nurses in implementing Universal Precaution. Based on these results it is necessary to maintain the consistency of nurses to always apply universal precaution appropriately according to the patient's condition at hand

Corresponding author:

Wansuzusino

and other health care centers. Standard Precaution can prevent transmission of disease / microorganisms (Duerink, et al. 2006). The principle of universal precautions is to assume all patients are affected or infected by microorganisms, with or without signs and symptoms so that a uniform level of prevention must be 
used in treating all patients (Smeltzer, et al, 2009).

Universal Precaution (UP) ie. a way of handling that must be applied by health workers to minimize exposure to blood and body fluids from all patients who are sources of infection regardless of diagnosis or infection status (ICN, 2009). This method was first introduced by the Centers for Disease Control and Prevention in the United States in 1987, one of its main objectives is to protect health care workers from disease transmission in health facilities by stressing the importance of treating all patients as potential contagious infections so that steps need to be taken adequate prevention (Isa, 2006, from Khairudin 2007).

Health workers have the potential to be exposed to blood during their duties and therefore they have the risk of being infected with diseases caused by pathogenic germs, such as HIV, hepatitis C virus, and hepatitis $B$ virus. Blood exposure can occur through percutaneous injury (needling or other sharp objects) ), mucocutaneous incidents (splashes of blood or body fluid mixed with blood on the eyes, nose or mouth) or blood contact with normal skin (Kermode, et al, 2005).

WHO (2002) estimates that among 35 million health workers worldwide, around three million have experienced percutaneous exposure to blood-borne viruses each year (two million HVB, 900,000 HCV and 300,000 HIV). This incident is estimated to result in infection of 16,000 hepatitis C, 66,0000 hepatitis B and $200-5000 \mathrm{HIV}$. More than $90 \%$ of these infections occur in low-income countries and whereas in developed countries can be prevented (Kermode, et al., 2005)

According to Nopriadi, et al. (2004), hospital staff who have a high risk of getting nosocomial infections include: doctors, nurses, midwives and laboratory workers, given that these officers always check and make direct contact with patients. As health workers who are in the front lines of each health service center, nurses are always exposed to various cases of illness, this is very risky to the health of the health workers themselves. Research conducted by Anwar (2005) shows that universal precautionary procedures are still often ignored, influencing factors are lack of knowledge and lack of funds needed to support the implementation of universal precautionary procedures (Khoirudin, 2007).

According to Harris, Nicolai and Richmond (2010), that almost all Emergency Medical Service sites make a report if they are exposed to blood and body fluids, and they are aware of the risk of hepatitis and HIV. In addition EMS officials were found to be inconsistent in applying the precaution standard when treating patients or when using syringes, such as not wearing gloves $17 \%$ and not removing contaminated objects (19\%), including needles (87\%) at any time. There were also reported cases of $40 \%$ needle recapping, $1.4 \%$ lanceolate, and $4.5 \%$ needle puncture.

Officers in the emergency room have a high risk of occupational infections by pathogenic germs through the blood, but unfortunately, according to Evanoff, et al (1999) reported that adherence to the application of universal precaution is still low in clinical high-risk settings. Compliance with the use of PPE is influenced by knowledge, attitudes, perceptions of risk, and organizational climate. In addition, the availability of PPE and convenient or easy use also have an effect. Differences in the level of adherence to PPE observed between different work groups indicate that interventions designed for certain groups may be needed for changes in effects in the use of PPE and other precautions against blood-borne disease transmission. 
The procedure of universal precaution must absolutely be implemented in all health care centers, such as in emergency rooms, action rooms, triage rooms, observation rooms and laboratories, as well as in ambulances. Various nursing procedures, both invasive and noninvasive, allow nurses to be exposed to germs that come from patients through blood and bodily fluids that contain blood. All nurses must apply universal precautionary procedures that are appropriate and consistent, at all times carrying out nursing actions for all patients, because in addition to selfprotection, also to prevent cross infection to patients or colleagues. Universal precautions require nurses' abilities as executors, supported by facilities and infrastructure, as well as Standard Operating Procedures that regulate universal precautions. Health workers must get protection from the risk of contracting the disease in order to work optimally (Mahardani, 2010). The purpose of this study is to determine the factors that influence the behavior of Indonesian nurses in implementing universal precaution in the Health Service Center in Qatar.

\section{METHODS}

The study was conducted with a descriptive correlation method which is a study conducted to analyze the relationship between two research variables, namely between the independent variable and the dependent variable (Nursalam, 2008). The design used is the Cross Sectional approach. The sample in this study were all Indonesian nurses in Qatar, amounting to 65 people (INNA Qatar, 2011). This research was conducted at the Indonesian Nurses Community in Qatar, the Qatar Indonesian National Nurse Association (PPNI), which was carried out in October 2011. Data collection tools with questionnaires and observation sheets. Data were analyzed univariately, bivariately (Pearson Product Moment correlation, Spearman Rank. KolmogorovSmirnov test).

\section{RESULTS}

The results obtained by Indonesian nurses who work in Qatar are mostly men, aged less than 40 years and have a DIII education. In general they have ample work experience> 10 years. Indonesian nurses working in Qatar health care centers are scattered in several work locations, such as; in ambulances, in company clinics, and hospitals, and there are also those who work in ambulances and clinics. Most Indonesian nurses, have a positive attitude, and have high motivation, and expressed supportive means for the implementation of Universal Precaution. Indonesian nurses mostly have positive behavior towards the implementation of universal precaution.

Normality test results for knowledge, means and behavior variables, the significance value is less than 0.05 , then the data is not normally distributed, while the normality test for attitude and motivation variables, the significance value is greater than 0.05 , then the data is normally distributed.

Obtained results there is no significant relationship between behavior with knowledge nurses, between attitudes with nurses' behavior, between motivation and behavior (Table 1).

Table 1

Correlation of Knowledge, Attitudes and Motivation with Nurse Behavior in implementing Universal Precaution

\begin{tabular}{lcc}
\hline Indicator & $\begin{array}{c}\text { Correlation } \\
\text { coefficient }\end{array}$ & $\mathbf{p}$ \\
\hline Nurse Knowledge & -0.260 & 0.063 \\
\hline $\begin{array}{l}\text { The attitude of the } \\
\text { nurse }\end{array}$ & 0.037 & 0.797 \\
\hline Nurse motivation & 0.159 & 0.260 \\
\hline
\end{tabular}

There is a meaningful relationship between facilities and infrastructure with behavior (Table 2). 
Table 2

Correlation of Facilities and Infrastructure with Nurse Behavior in Applying Universal Precaution

\begin{tabular}{lcc}
\hline Indicator & $\begin{array}{c}\text { Correlation } \\
\text { coefficient }\end{array}$ & $\mathbf{p}$ \\
\hline $\begin{array}{l}\text { Facilities and } \\
\text { infrastructure } \\
\text { available }\end{array}$ & 0.458 & 0.001 \\
\hline
\end{tabular}

\section{DISCUSSION}

Indonesian nurses working in Qatar, mostly aged between 30 - 39 years old. Characteristics of Indonesian nurses working in Qatar are mostly in the early adult phase so they have emotional maturity and can make the right decisions in carrying out their roles and functions as professional nurses. According to Berg (1996) age is the age of the nurse who outlines an indicator in the maturity of each decision-making that refers to each of his experiences (Rozulaina, 2007).

Indonesian nurses who work in Qatar, in general, have had enough previous experience, where most respondents have a tenure of $>10$ years Before working in Qatar, they have worked in company clinics in Indonesia, and in hospitals, both in Indonesia and abroad. Siagian (1995) states, one's service life in the organization needs to be known, because tenure is one indicator of productivity and work motivation. Furthermore Siagian assumes that the longer a person works in an organization the higher the productivity, because he is more experienced and has high skills in completing tasks, but it is not impossible the opposite happens, that people who have long worked in the organization will show symptoms of decreased motivation and productivity work. If someone gets a good work experience in the past, it will also have a good effect in the new workplace, but conversely if the experience of something less certainly will affect the new work environment.
The study described that male respondents were more dominant because the nurses' admission system from Indonesia in Qatar at this time was still dominated by male nurses, while female nurses were generally local. Gender is the respondent's identity that is used to distinguish male or female nurses. Siagian, (1995) states that there are certain types of work that are suitable for women or men. And the nursing profession is seen as a female profession, but it is also possible for men to enter the profession, but in small numbers.

The study explained that Indonesian nurses in Qatar, most of them were Nursing Academy graduates. Which means that most Indonesian nurses are still at the level of semi-professional (vocational) nurses. Low education level, but have a long working experience, will affect the behavior of nurses. The higher level of nurse education can influence nurses' behavior in applying universal precaution appropriately and correctly. The results of research on Indonesian nurses have a high level of knowledge about universal precaution. High knowledge about universal precaution can encourage someone to behave according to the expected standard. Knowledge of how diseases are transmitted and their prevention can encourage nurses to apply universal precaution appropriately and correctly.

The study showed that most Indonesian nurses had a positive attitude towards the adoption of universal precaution. A positive attitude of nurses can encourage nurses to behave positively towards the application of universal precaution to prevent transmission of disease, from patient to nurse and vice versa from nurse to other patients. The results showed that most Indonesian nurses were highly motivated. Motivation can arise from within an individual or come from the environment for someone and what gives direction to their activities 
The results of research on Indonesian nurses showed that the majority of respondents stated the means of support. The availability of facilities at work is one of the factors that influence the formation of compliance and includes enabling factors (Green, 2000). If the facilities and facilities are insufficient in the working environment, it is certainly difficult to achieve the goals of an organization. The availability of facilities and infrastructure has a very important role among other factors that influence the behavior of nurses in the application of universal precaution, because without the means and infrastructure, standard precaution cannot be applied precisely and consistently.

The results obtained by the relationship between knowledge and behavior of nurses that are not significant ( $p<0.05)$ These results are in line with the study of Regina, et al (2001) in Hong Kong, which showed no significant relationship between nurse knowledge and compliance with Universal Precaution and It is recommended that Universal Precaution training programs need to be considered to be combined with empirical knowledge. But this is different from the results of research conducted by Karmode, et al (2005), which states that some actions that need to be emphasized to improve the compliance of health workers in the application of universal precaution, not only their knowledge and understanding, but also the importance of creating a safe environment by the organization that hired him. According to the results of research conducted by Ndikom and Onibokum (2007) there is a significant relationship between knowledge and behavior in HIV prevention among health workers in Nigeria. According to the authors knowledge of how disease transmission and prevention can encourage nurses to apply universal precaution appropriately and correctly. However, high knowledge about universal precaution must also be supported by facilities / facilities available at the workplace agency.
The results obtained by the correlation between attitude and behavior of nurses were not significant at ( $p<0.05)$. Research conducted by Oliviera, et al (2009) states that despite the fact that staff have adequate knowledge about universal precaution, they fail to behave appropriately in their actions to reduce the risk of spreading infectious agents and causes of work accidents. Although there are still some respondents who are negative about universal precaution, it does not prevent them from continuing to apply universal precaution that is true and right in the workplace. Whereas Askarian, et al (2005) conclude that strong support for the achievement of the implementation of the standard precaution guidelines depends on several factors such as optimal awareness and positive attitudes each health worker has, and this goal cannot be achieved without continuing training by quality staff, as often mentioned in various literature. According to researchers a positive attitude needs to get support from other factors so nurses can behave optimally in applying universal precaution.

The results obtained by the correlation between attitude and behavior of nurses were not significant at $(p<0.05)$. These results are not in line with the results of research conducted by Khairudin (2010) which concluded that there is a significant relationship between nurses' motivation in implementing universal prevention. Mark Cole, (2005) states that a motivational teaching approach is needed in changing the behavior of health workers to increase the level of compliance in applying hand washing before and after taking medical action. The author assumes that nurses' motivation in behavior in the application of universal precaution is not always consistent, because motivation can be influenced by factors of encouragement from within the individual, as well as outside the individual.

The results obtained by the correlation between attitude and nurse behavior were 
significant at $(\mathrm{p}<0.05)$. This is in line with the results of research conducted by Efstathiou et al (2011), stating that one of the inhibiting factors of health workers in implementing universal precaution is the unavailability of appropriate facilities and infrastructure when they need it. While the results of research conducted by Ndikom and Onibokum (2007) state that the facilities and infrastructure needed in practice must always be available, and so also the workplace environment must be sufficiently conducive to the application of universal precaution. These facilities and facilities essentially support or enable the realization of a behavior, so it is called a supporting factor or enabling factor (Green, 2000). Facilities and infrastructure in the nurse's workplace environment have the greatest influence on the application of universal precaution, because without adequate facilities and infrastructure, it is not possible for a nurse to apply universal precaution that is appropriate and consistent.

Limitations that exist in this study include the use of the study correlation approach method so that the relationship determined from the independent variable and the dependent variable is not a causal relationship, because the study was conducted at the same time and without any follow-up. And the absence of controlling factors in this study. With the limited number of respondents available, so that if this study is conducted with a larger number of samples, it will certainly produce better results. And there are still other factors that can be used as independent variables in this study, such as level of education, length of work experience, perceptions, sources of funds and others. Data collection using a questionnaire has a very subjective impact so that the truth of the data depends on the honesty of the respondents. Researchers have not found the standard standard questionnaire so that the instrument is based on the understanding and experience of the researchers themselves, which of course is still limited as a beginner researcher. The questionnaire was used for the first time although the results of the validity and reliability tests were quite good but only one research site was limited. Appropriate and consistent application of universal precaution is very important for a nurse to provide nursing care to the clients.

\section{CONCLUSION}

The results of the study of the factors influencing the behavior of Indonesian nurses in implementing universal precaution at the Qatar Health Service Center, namely: the majority of Indonesian nurses working in Qatar are male, aged less than 40 years old, have a DIII education, already have considerable work experience , spread across several work locations, such as; in ambulances, in company clinics, in hospitals, while most work in ambulances and clinics. There is a relationship between the availability of facilities and infrastructure with the behavior of Indonesian nurses in carrying out universal preventive action procedures in the work environment. There is no relationship between the level of knowledge, attitudes and motivation of nurses on the behavior of Indonesian nurses in carrying out universal preventive action procedures in health care centers.

\section{ACKNOWLEDGEMENTS}

We wish to express our appreciation to all respondents who participated in this study for valuable assistance during data collection.

\section{CONFLICTS OF INTEREST}

Neither of the authors have any conflicts of interests that would bias the findings presented here. 


\section{REFERENCES}

1. Asmadi. (2008). Konsep Dasar Keperawatan. Jakarta. EGC

2. Cole, Mark. (2005). Using a Motivational Paradigm to Improve Hand Washing Compliance. United Kingdom. (www.elsevierhealth.com/journals/nepr diakses 24/12/2011)

3. Duerink, d.k.k, (2006). Preventing nosocomial infections: improving compliance with standard precautions in an Indonesian teaching hospital. Journal of Hospital Infection (2006) vol. 64: 3643

4. Efstathiou, d.k.k, (2011). Factors influencing nurses's compliance with Standard Precaution in order to avoid occupational exposure to microorganism: A focus group study. BMC Nursing 2011, 10:1 http://www.biomedcentral.com/14726955/10/1 (diakses 23/12/2011)

5. Evanoff, B \& dkk (1999). Compliance With Universal Precautions Among Emergency Department Personnel Caring for Trauma Patients. by the American College of Emergency Physicians. Inc. (International Journal Nursing Study. Vol 33 no 2 p 143-160)

6. Green, L.W., \& Kreuter, M.W. (2000). Health promotion planning an educational and environmental approach. (2nd ed.). Mountain View: Mayfield Publishing Company.

7. Harris, S.A, Nicolai, L.A. (2010). Occupational exposures in emergency medical service providers and knowledge of and compliance with universal precautions. USA, APICE, publikasi oleh Elsevier Inc. (American Journal Infection Control 2010: 38. 86-94)

8. ICN. (2009). Nursing Matter: Infection Control. Fact Sheet. Jenewa, Swiss

9. Kermode, M et.al (2005). Compliance with Universal Precaution among health care workers in rural India. Australia. Association for Professional in Infection Control and Epidemiology, Inc.

10. Khoirudin, A (2010). Faktor-faktor yang mempengaruhi perilaku perawat dalam menerapkan prosedur tindakan pencegahan universal di instalasi bedah sentral RSUP Dr. Karyadi Semarang.Unimus (Skripsi) Tidak dipublikasikan.

11. Kusnanto. (2003). Profesi dan Praktik Keperawatan Profesional. Jakarta. EGC

12. Mahardani, R. (2010). Faktor-faktor yang mempengaruhi kepatuhan perawat dalam menerapkan Universal Precaution ketika melakukan kemoterapi pasien kanker di RSUD Dr. Moerwadi Surakarta. UMS (Skripsi), Tidak dipublikasikan.

13. Notoatmodjo, Soekidjo. (2003). Pendidikan dan Perilaku Kesehatan. Jakarta: PT. Rineka Cipta PT. Rineka Cipta
14. Nursalam \& Kurniawati, N.D. (2007). Asuhan Keperawatan Pasien Terinfeksi HIV/AIDS. Jakarta. Salemba Medika

15. Nopriadi, Kusnanto, H. dan Hersusanto. (2004). Evaluasi program pengendalian Infeksi nosokomial terhadap petugas di RS: Suatu kajian di ruang rawat inap RSU PKU Muhammadiyah Yogyakarta. Program Pasca Sarjana UGM (Thesis).

16. Oliviera, d.k.k, (2010). Knowledge and attitude regarding standard precautions in a Brazilian public emergency service: a cross-sectional study. Source (publmed.gov. USA http://www.ncbi.nlm.nih.gov/pubmed/ (diakses 24/12/2011)

17. PPNI cabang Qatar (2011). Indonesian Nursing National Association Qatar

18. Priharjo, R (2008). Konsep dan Perspektif Praktik Keperawatan Profesional. Edisi 2. Jakarta. EGC

19. Regina, Chan. d.k.k. (2001). Nurses' knowledge of and compliance with universal precautions in an acute care hospital. Hongkong (www.elsevierhealth.com/journals/nepr diakses 24/12/2011)

20. Rozulaina, A (2007). Hubungan Karakteristik Perawat dengan Kinerja Perawat dalam Asuhan Keperawatan di BRSD RAA Soewondo Kabupaten Pati Unimus.

21. Santoso, Singgih (2010). Statistik Parametrik. Jakarta. PT Elex Media Komputindo,

22. Siagian, Sondang P. (1995). Teori Motivasi dan Aplikasinya. Rineka Cipta, Jakarta.

23. Stoy, W.A, Platt, T.E \& Lejeune, D.A (2005). Mosby's EMT-Basic Text Book (2nd edition). USA, Elsevier Inc.

24. Smeltzer, S.C. d.k.k (2009). Brunner and Suddath's: Texbook of Medical Surgical Nursing (11th Ed). New Delhi. Lippincort and William. p 2124

25. Swansburg, R.C \& Laurell (2001). Pengembangan Staff Keperawatan: Suatu Komponen Pengembangan SDM. Jakarta. EGC

26. Sarwono, J (2011). Teori Analisis Korelasi: Mengenal analisis korelasi http://www.jonathansarwono.info/korelasi/ko relasi.htm/ diakses 2/1/2012.

27. Sunaryo. (2004). Psikologi Untuk Keperawatan. Jakarta EGC 